\title{
Regional Security Arrangements and Foreign Policy of the Islamic Republic of Iran Case Study: Shanghai Cooperation Organization
}

\author{
Ebrahim Javadi Veshki ${ }^{1} \&$ Majid Divsalar ${ }^{1}$ \\ ${ }^{1}$ Department of Political Science, Ayatollah Amoli Branch, Islamic Azad University, Amol, Iran \\ Correspondence: Majid Divsalar, Department of Political Science, Ayatollah Amoli Branch, Islamic Azad \\ University, Amol, Iran. E-mail: m.divsalar56@gmail.com
}

Received: May 14, 2016 Accepted: June 15, 2016 Online Published: July 31, 2016

doi:10.5539/jpl.v9n6p1 URL: http://dx.doi.org/10.5539/jpl.v9n6p1

\begin{abstract}
In international system scene, interests and strategies for ensuring these interests are among key strategies of powerful countries. Therefore, super powers, organize security in different geographical areas through competition in order to challenge competitors and threaten them. Shanghai cooperation organization (SCO), as the most important security measure, has been developed by influence of competitive atmosphere in international system by help of Russian, China and some other important regional allies in response to transatlantic actions. As a result, this security measure could control peripheral threats in the region. In this regard, Islamic Republic of Iran, has considered emergence of this regional security measure as a serious threat for its national and regional interests and has acted to suppress them in the framework of its defense diplomacy. Considering this, authors try to answer this question that how Shanghai cooperation organization as security measure can influence the foreign policy behavior of Islamic Republic of Iran? By studying and analyzing how and why Shanghai cooperation organization (SOC) around Islamic Republic of Iran and determining foreign policy of super powers in establishing this organization, its effect on the foreign policy behavior of Islamic Republic of Iran is considered.
\end{abstract}

Keywords: regional security, security Arrangements , competition, Shanghai, international system

\section{Introduction}

Islamic Republic of Iran, due to its geopolitics position in the Middle East and geographical proximity with some countries in Central Asia, was always influenced by regional security Arrangements caused by strategic competition of super powers and in order to reduce security threats developed from environment and to help the improvement of regional security, has selected cooperation-based security approach and participation of regional players in resolving the challenges and security dilemma caused by competition atmosphere.

Shanghai corporation organization (SCO), during it life-cycle as an effective regional measure, has been faced convergence challenges. Capacities of this organization are such that it can have horizontal and vertical development. This means that this organization can both develop relationship with other countries and organizations and attract new members and also can define a broad mission for itself and implement it. SCO must take other steps in order to become an important regional power and effective player in international space.

According to political analysts, effective factors like common interests of countries, common norms and emphasis of members on changing the status quo have succeeded these countries in achieving the goals of organization. Relationship between China and Russia in this group is important and fundamental. These two super powers form the foundations of SCO and their cooperation is necessary for this organization. Although both countries oppose emerging a monopole global order, but they have not convergent strategic relations yet.

This conditions have caused that Islamic Republic of Iran intends to become member of this organization, because it visualized opportunistic and threat-based look to SCO for itself. Therefore, joining Islamic Republic of Iran to SCO have twofold effect:

First, it attracts cooperation of members in this group and by developing close relationship with important countries in the region, it can somehow compensate consequences of its revolutionary policy and problems of relationship with west (led by US). Second, this movement can be explained in line with policy of developing relationships with east and approaching China which explicitly opposes international dominance of US. 
Therefore, the strategy of Islamic Republic of Iran for SCO as a regional security measure is based on eliminating threats and nullifying effective behavior in such a process (Divsalar, 2011: 87).

\section{Literature Review}

The SCO combination of goals of political, security and economic pursuing simultaneously. The Shanghai Cooperation Organization has been analyzed in the context of the national interests of the United States, Russia, China, and Central Asian states.in the other hand Iran is quite a natural partner for the SCO member states for a wide range of reasons, from geography to trade and economics. In 2005 Iran joined SCO as an observer member, and then applied for full membership. This application raised a lot of debates inside Iran, inside SCO members and in the international polity. Despite some views inside Iran against membership in this organization, the majority of Iranian analysts as well as the dominant authorities and decision makers of Iranian foreign policy supported and followed its membership application in the SCO. Yet the road to membership is not smooth for Iran. Although Iran's membership in the SCO seems remote in the shadow of Western pressures over Iran's nuclear profile, it depends on the international political environment and future events which can change calculations.

\section{Establishment of SCO as a Regional Security Measure for Achieving Interests}

By collapse of Soviet Union, major changes occurred in geopolitics of China and Russia borders and a part of common border between these two countries has become common border among China and Kazakhstan, Tajikistan, Kirgizstan and Russia. In 1990, China has used an approach in its foreign policy that have two elements maintaining the international peace and opposition with any hegemony on regional and international level and economic renovation in national level and for achieving this, tension free atmosphere was necessary (Zahedi Anaraki, 2006: 110-111). By collapsing soviet, problems like ethnocentrism, fundamentalism and extremism are added to the border problems. Due to presence of Muslim Uyghur's in west state Sin Kiang and autonomous movements, China has exposed more than other countries to these dangers. Therefore, heads of five countries Kazakhstan, Kirgizstan, Tajikistan, Russia and China have gathered in April 26 in shanghai and reached to an agreement for martial and border issues. Based on the agreement, they committed to avoid aggressive behavior against each other and try to maintain regional security. This meeting was called "Shanghai $5 "$. By permanent membership of Uzbekistan in 2001, SCO was formally established in June 15 of that year.

\section{Goals and Principles of SCO}

Based on the article 1 of SCO charter, main goals of this organizations are:

1) Enhancing trust, friendship and mutual good adjacent among member countries;

2) Consolidating regular cooperation in developing and enhancing peace, security and stability in the region and promotion of new economic and political order based on the democracy, justice and reason;

3) Counter resistance against terrorism, separation and extremism in all forms, fighting against drug traffic and arm transportation and other transnational criminal activities and illegal migration;

4) Encouraging efficient regional cooperation in all fields like politics, trade and economy, defense, enforcement of regulations, preserving environment, culture, science and technology, education, energy, transportation, financial and credit issues;

5) Facilitating comprehensive and balanced economic growth, social and cultural development in region through joint action based on the equal participation in order to achieve sustainable development of life indicators and improving life of people in member countries;

6) Improving the condition of human rights and basic freedoms conforming international commitments of member governments and national regulations;

7) Supporting and developing relationship with other governments and international organizations;

8) Coordination of methods for convergence in global economy;

9) Endeavor and cooperation in preventing international conflicts and peaceful resolution;

Article 2 of SCO charter states the principles that governments should follow:

1) Mutual respect to sovereignty, autonomy, integration of government territory and non-violation of government borders, non-aggression, non-intervention in domestic affairs, avoiding applying force or threat in international relations, avoiding achievement to unilateral martial dominance in neighbor areas;

2) Equality of all member governments, studying common positions based on mutual understanding and respect 
for their thoughts;

3) Gradual application of common activities in mutual interests' fields;

4) Peaceful resolution of differences between member governments;

5) Prevention of each illegal activities against interests of SCO;

\section{SCO's Strategy toward Iran}

SCO's strategy toward Iran in the past decade can be described as "a biased approach toward an effective international actor." Therefore, on the one hand, the SCO's strategy toward Iran has been under the influence of two main forces of this organization, that is, China and Russia. On the other hand and through a more in-depth analysis, it has been affected by the United States' aggressive reaction to Iran's foreign policy orientations and approaches followed by the application of the sanctions and threat policy against Iran. In their approach to the SCO, China and Russia have seen this world body and its actors as a tool in the geopolitical expanse of the world's heartland, which can be used for bargaining and meeting the maximum degree of their national interests. In its first step toward geographical expansion within the international system, the SCO has been trying to attract new members in order to boost the international credit and prestige of its major actors. As a result of this kind of look at countries like Iran, Tehran's membership request was finally granted in 2005 and the country became an observer member of the organization. From 2005 to 2015, Iran's participation in the SCO's meetings was considerable. However, due to later limitations, partly as a result of the bureaucratic red tape, and partly blamable on positions taken by the main members - Russia, China, Uzbekistan, Tajikistan, Kyrgyzstan, and Kazakhstan - and also due to Iran's foreign policy restrictions as a result of Tehran's nuclear case, the permanent membership of the Islamic Republic in this organization has not been realized yet.

Having the cooperation of powerful partners like Iran will increase the influence of the SCO in such areas as fighting terrorism and drug smuggling; elimination of poverty and economic inequalities; preventing foreign interventions; bolstering regional security, realizing a multipolar world; strengthening border security; and overcoming border problems. In such fields, Iran's cooperation will have serious, powerful and long-term outcomes for that organization and its member states.

Due to anti-American positions of the SCO members during summits meetings in 2005 and 2006, and because of the sensitivity of the United States foreign policy about Central Asia, the SCO has been a focus of special attention for Washington since 2006. Since the current bipolar situation inside the SCO will actually turn into a tri-polar situation through full membership of countries like Iran, the main members of the organization have adopted a strategy of "biased approach toward an effective international actor" and have no serious plan to promote Iran's observer status to a full member in the short run. A possible paradigm change in the SCO may alter the situation of a country like Iran in the SCO summit meeting to be held in the Russian city of Ufa. Some reports have indicated that a change in the status of India and Pakistan from observers to full members is going to be discussed in the meeting.

SCO has been seen as the source of one of the most important geopolitical convergent capacities in the world which can create balance in rivalries among big powers, including those involving the North Atlantic Treaty Organization (NATO). However, according to the regional agenda of the SCO's organs, the organization doesn't seem willing or capable enough to move toward a full-blown confrontation with the Western alliance. Under these conditions, gaining maximum success in international and regional levels by ending its biased approach to such important and effective members as Iran would allow the SCO to realize part of its goals and strategic plans( Khoshandam,2015).

\section{Foreign and Security Policy of Islamic Republic of Iran about Formation of Regional Security}

Islamic Republic of Iran has always encountered various and continuous challenges and problems in its environment and these problems are reflected in all fields of this security environment such that this country has not yet observed stable and sustainable security framework in these fields. Previous security challenges of Iran which were originated from its environment were existed in different forms and included border insecurities and temporary instabilities to attacks and long term martial wars. This is now portrayed in different frames and components.

Recently, terrorism and extremism, weak governments and authority crisis and interventions of trans-regional interventions are three major security challenges around Iran which multi-dimensional and close relationship with each other. Among this, it seems that weak governments and authority crisis is more fundamental because it stimulates two other components like expansion of terrorism and extremism and developing penetration and intervention of trans-regional powers. Fragile governments in Iraq, Afghanistan and Pakistan have expanded 
terrorisms and extremism and in addition, they have provided the ground for continuous presence of trans-regional powers. In Arabic countries of Persian Gulf border, authority crisis and weakness of governments have provided ground for asymmetrical cooperation with trans-regional powers and increased intervention of foreign powers (Vaezi, 2007: 17).

These problems, regarding ethnic and social texture of region and special experiences of nation-states, complicate the security conditions. Ethnic differences, authoritarian governments, legitimacy crisis, lack of democracy and civil bodies along with poor economy in some countries in central Asia and Caucasus are other factors which lead to instability and insecurity in security context of Iran. Terrorism and religious and ethnic extremism has increased in the region during recent years and this significantly increases order and political-social stability and economic development of countries. Wahhabi and Salafism as an extremist religious ideology is major source of expanding terrorism and religious tensions and this ideology, due to regional disturbances and some political considerations of beneficiary actors, has found widespread space for expansion and influence. All these threats and subjects can influence the security of Islamic Republic of Iran in organizing regional and trans-regional organizational security by super powers.

\section{Islamic Republic of Iran and Shanghai Cooperation Organization (SCO)}

Formation of Shanghai Cooperation Organization (SCO) as the first security after cold war has reaction of regional and trans-regional actors, especially super powers. Some important regional and trans-regional actors like Mongolia, India, Pakistan, Afghanistan, Iran and US have shown their tendency for cooperation in different fields. In 2004, membership of Mongolia as supervisor member was accepted. In next year, in June 2005, in $10^{\text {th }}$ summit in Astaneh city, members of organizations have approved membership of Indian, Pakistan and Iran in order to enhance and expand the activity scope of organization (Mattis, 2005: 67). Definite principle in foreign policy of Islamic Republic of Iran against regional security treaties and organizations is avoidance and not joining. Presence of two regional-global powers i.e. China and Russia in SCO, which were against formation of unipolar system, was attractive for Iran due to its conflicts with US. Iran imagined that by membership in an organization which clearly opposes formation of unipolar system and is considered as a serious challenge for US hegemony, it can ensure its security.

Presence of two permanent members of Security Council in SCO and India as candidate for permanent membership in Security Council, in addition to increasing power of this organization in the region, has developed considerable capacity for its determinant role in forming global revolutions. Although we should consider that one fundamental strategy of Iran in foreign policy field is paying attention to regional corporation and convergence for resolving the problems of the region and achieving security, well-being, development and economic progress for nations, but changing the old policy of Iran for non-membership in regional security treaties, especially if super powers play role in it, should have more basic reason which is using structural opportunity of hegemony weakness and formation of anti-hegemon organization for providing national security.

Interests of Iran and two super powers of SCO i.e. Russia and China for prevention of US penetration in South-west Asia, especially central Asia, has approached them to each other in bilateral and multi-lateral ties in framework of SCO. Iran requested membership in SCO because it has found this characteristic i.e. opposition of organization by formation of unipolar system led by US. During office of Seyyed Mohammad Khatami, Iran requested to become member of this organization in order to resist against hegemony of US, although foreign policy of Khatami government was based on the interaction with west and US and he believed that through constructive coalition with west for national interests of Iran, security will be ensured and have less reliance to east, but due to problems appeared in the last years of his office with west (declaring Iran as axis of evil and lack of desired result in nuclear negotiation with European countries), Iran has revealed its tendency toward east.

Government of Mahmood Ahmadinejad has changed foreign policy of Iran and he declared the policy of looking toward east. In one hand, experience of Khatami's interaction with west was not positive and Iran has recessed in all fields, especially in nuclear negotiation and has not obtained any privilege; on the other hand, it seems that Ahmadinejad wants to be different with previous government which considered is as its political antithesis. But an important point was that Ahmadinejad and his allies believed that fundamental problem of Iran and west is in the nature of Islamic Republic of Iran not in its policies.

Khatami believed that foreign behavior of Iran has destroyed the trust of west and this atmosphere can be broken by a new pose and more balanced behavior. Therefore, he has raised the thesis "dialogue of civilizations" and tried for eliminating tensions and trust building. But government of Ahmadinejad believed that problems of west, especially US, is deeper than this and threat of US (dominated by policies of Israel) is a strategic threat and changing the behavior of Iran will not develop just relationships between Iran and these countries, but as nuclear 
negotiations showed, their expectations will be increased. Therefore, Ahmadinejad believed that he should take more active policy in foreign policy and retreat against west is harmful for Iran; therefore, they changed foreign behavior of Iran. Among these changes was declaring "east look" policy by government including active diplomacy for membership in SCO. The major goal of this policy is equilibrium with west. New policy makers in foreign policy of Iran believe that one of the best ways to resist against US is unifying with Asian countries. Therefore, they are seeking for active presence in SCO which is in clear opposition with global system led by US A brief look to speeches of Iranian authorities, especially Ahmadinejad, indicated the fact that major goal of Iran for membership in SCO was exploiting its potential for resisting against US hegemony and providing security and national interests of Iran (Divsalar, 2008: 23).

In sum, increasing cooperation of China and Russia and their tendency for resisting against penetration of US in central Asia, has encouraged Iran for higher cooperation with this organization in order that by exploiting this geopolitics fear of both countries, it approaches its regional goals which are based on the ensuring regional security. Iran knows well that preventing US penetration in central Asia and formation of multipolar international system are main goals of Shanghai members, especially China and Russia and Shanghai is transforming to a new power that prevents formation of US hegemony. Unilateralism of US, taking explicit and severe positions increases the opposition against presence of US in the region and places it in more clear opposition with US hegemony. These imposed policies and declarations of power in SCO have encouraged Iran for membership of this organization in order to resist the hegemony of US.

\section{Reasons for Importance of SCO for Iran}

At least six reasons can be presented to answer this question that why SCO should be considered seriously:

First, globalization has increased coalitions and they became more important. For this reason, many coalitions and organizations become active and enhanced and countries state their wants and interests in the framework of some convergent countries.

Second, capacities of SCO and its competences regarding membership of two members of five permanent members of Security Council in this organization, having more than one-third of world population, considerable area and economic capabilities promise a powerful potential coalition and if four observer countries Mongolia, Iran, Pakistan and India added to this group, $\mathrm{SCO}$ with population of 2.7 billion and half area of earth will reach to the more important position.

Third, many analysts believe that current century is the century of Asia and many power equilibriums in global level are determined in this region and therefore, importance of Asia in the future of international system is increasing and it is necessary that Asian powers define a new position for themselves in the new international system.

Fourth, this organization cannot remain as a regional organization in future because presence of two super powers China and Russia in transformed conditions of world will pose this organization as a trans-regional organization. Even if the primary goals of China and Russia leaders from establishing SCO was regional, this organization has suitable opportunity for exchange in international issues and common global concerns.

Fifth, capacity building for expansion of regional economic cooperation is necessary. In the framework of these bodies, the opportunity for developing trade and mutual investment and development of industrial and economic cooperation increases.

Sixth, considering certain regional and international condition, Iran needs to cooperate with larger regional and international countries and define some of its interests and wishes in that framework.

Globalization has increased coalitions and its importance has been increased. Therefore, in last decade, many coalitions and organizations became active and enhanced and countries seek their interests in the framework of convergent countries. Capacity of SCO and its ability, by having one-third of world population, considerable area and economic capabilities promises a potential powerful coalition.

Islamic Republic of Iran, since the establishment of SCO, always has followed activities and constructive role of members of this organization as an effective body in the events and political and economic events of world and has supported some goals of this organization including consolidation of trust, mutual friendship between member countries, development of cooperation for maintaining peace, security and stability in the region, common encounter with terrorism, separation and extremism, drug and arms control and by being observer member of this organization in 2005, has shown the tendency for cooperation and has tried for development of SCO goals (Alavian \& Koozehgar, 2009: 25). 
Today, extremism and terrorism is an important political and security problem in the regional and global level and it seems that extremists penetrate in the region and SCO member countries and challenge the security of these countries. Regarding that Islamic Republic of Iran is a pioneer country in fighting against extremism and regional terrorism, this country is ready to share its experiences with SCO countries and take active role for enhancing security and stability of region.

Cooperation for fighting against drug traffic is an important concern of this organization. In this regard, we can refer to the important role of Iran in previous years in fight against drug traffic from Afghanistan. Financial costs and casualties of Iran in fight against drug traffic were very significant and have been acknowledged by UN and different countries. In addition to developing relations, Iran cooperates with other members in bilateral ties in multilateral format to fight against drug traffic. This capacity is an added value for the actions of this organization.

Purpose of joining countries in the region, especially Iran, to SCO is cooperation and synergy between economic capacities of region and fight against security threats and this organization can enjoy results and positive interests of members and collective capacities. Geostrategic position of SCO between two developed poles of the world i.e. East Asia and West Europe has empowered this organization in terms of infrastructures.

Development of business and economic cooperation to achieve sustainable regional stability is a strong approach for enhancing SCO. This organization has increasing capacities and resources that emphasis on their development in the light of presence of China and Russia can balance international regional equilibrium. Capacity building for development of regional economic cooperation is necessary and in the framework of these bodies, the opportunity for business and mutual investment and development of industrial and economic cooperation increases.

Regarding specific regional and international condition, Iran intends to cooperate with larger regional and international bodies in different ways and forms and define some of its interests and demands in that framework. Iran is interested to cooperate with SCO in economic and business, energy, transportation and transit fields. Common interests of Iran and SCO members necessitates the cooperation and high capacity and role of Iran in $\mathrm{SCO}$ is useful for economic relations with other partners in the Asia.

Iran is fourth oil producer in the world and has second gas reserves in the world, rank 10 in tourism industry and highest and largest industries in Middle East and North of Africa and fourth place in diversity of agriculture products. Geographical position of Iran, due to locating between east and west, has important role in developing economic relations and cooperation of SCO member countries. Therefore, cooperation between Iran and SCO has increased in recent years,

Regarding increase in energy consumption of the world and presence of large energy producers and consumers countries in SCO, there is suitable ground for cooperation in energy and important position of Iran is highlighted here. Iran is a large producer of oil and has considerable gas reserves and has close cooperation with SCO member countries like Indian and China to meet part of their energy needs. Market of Iran is open to SCO member countries for excavation and extraction of hydrocarbon fields (Javadi, 2015: 85).

By increasing economic exchanges and forming interdependence structure in international system, importance of topics like transportation and transit reveals and in fact, one important dimension of globalization is complex structure of interdependence in economic dimension that all international actors play their role in it depending on their capacities. Iran, due to its geographical position, is located in the important international transportation corridors including north-south corridor which connects India and free oceans of south through Iran to Caucasus, west Asia and Mediterranean Sea. Asia railway corridor which connects countries in south-east of Asia and India to Turkey and East Europe through railway.

Other economic fields are important for cooperation of Iran and SCO, especially, since Iran is interested in good future economic projects of SCO member countries i.e. "Eurasia economic union" and "silk road economic belt" and intends to cooperate and play role in both projects. Iran intends to establish free business regime with Eurasia economic union and considers close cooperation with this union as a ground for developing economic cooperation with these countries. In addition, Iran had important role in old Silk Road and highways of region and supports the new Silk Road plan. It is suitable to think about conformity of Eurasia economic union, new Silk Road and economic cooperation in SCO framework.

Iran is interested in cooperation in different economic sectors with SCO member countries including agriculture, production of non-fossil energies, telecommunication, electronic communications and enhancing bank cooperation and mutual support of investment between SCO member countries. Therefore, permanent 
membership of Iran in this organization will influence its economic ties with other member countries and provide more opportunities for cooperation with them.

By formal joining of Iran to SCO, this organization will have widespread cooperation and its participation and penetration in international issues increases. Formal membership of Iran in SCO means higher cooperation and communication among members. If Iran became formal member of SCO, widespread cooperation will occur in different sectors including tourism to exchanging human labor, energy, resources, culture, humanitarian aids and economic issues. It is expected that regarding the implementation of Iran and G5+1 agreement and lifting sanctions, formal membership of Iran become more series in post-sanctions era (Divsalar, 2014: 19).

\section{Conclusion}

Various security organized by great powers in different regions of world have created new challenges for countries in those regions. Therefore, each measure is defined in a mission format for limiting rivals and imposing authority to the countries in those regions which has reactions of rivals and countries. New missions of NATO (as actions out of this treaty competence in legal terms) and conducting these out of traditional scope, increases the importance of this security concern about effect of these mission on the interests and security of Islamic republic of Iran.

Shanghai cooperation organization, from beginning, has follows its purposes step by step and in each step, has accepted new members corresponding to new goals. This organization was first established for trust building in the common borders among Russia, China and three Central Asia countries and in next step, by emerging terrorism and religious extremism, fighting against it became priority of SCO and along with it, Uzbekistan which was more exposed to extremism, was accepted in this organization. In current step, considering that four countries Mongolia, Iran, India and Pakistan are observer members, goals of organization have extended to the next step and seek to develop tension-free region without military presence of US in advanced east and highly-tensioned west of Asia. In these conditions, it seems that talking about promotion of this organization to a security political organization in global level or and economic organization by membership of India and Pakistan and economic inequalities, is premature. In addition, in the case of this promotion, directions of organization will be based on the interests of China and Russia.

With broad look at SCO, an important thing for Iran is using this organization for developing and consolidating stability in the security environment because security environment in Iran has many alignments with member countries.

The importance of this subject becomes clear when we note that first, based on the perspective document, as a macro strategy of country, Iran must achieve first rank in scientific, economic and technologic fields in the south-west of Asia in next 20 years and second, in this condition, security environment of Iran is very disturbed and instable, since Middle East is one of the instable and dangerous regions of the world due to presence of Iraq, Afghanistan, Pakistan and Central Asia. Achieving rapid development and indicators of perspective document is very difficult in this security environment and is reveals the importance of stability and institutionalism for developing stability.

Therefore, we can say that, first, leaving cold war mentality needs understanding and correct definition of SCO and second, viewing it from political institutional angle for better management of interests and resolution of conflicts is rooted in reality. By relying on these two components, this organization can be considered as stabilizing tool for Iran and used it to develop stability in security environment of Iran and providing ground for reaching goals in perspective document.

Finally, Iran's strategy toward the SCO is influenced by the country's foreign policy goals and orientations, restrictions it faces at international and regional levels, and its attitude toward China and Russia as driving forces in this organization. On the whole, Iran's strategy can be discussed under the general heading of "increasing partnership in regional alliances." To understand historical developments related to Iran's strategic approach to the SCO, the country's historical attitude toward collective security, Iran's new foreign policy goals following the Cold War, as well as the country's needs, restrictions and motivations for interaction with the SCO from the victory of the Islamic Revolution in 1979 up to the middle of 2015 should be analyzed.

\section{References}

Alavian, M., \& Koozehgar Kalji, V. (2009). Foreign policy of Iran and Central Asia; grounds for convergence and divergence. Political sciences research, (51).

Anaraki, M. (2006). Shanghai cooperation organization, from theory to practice. Central Asia and Caucasus studies journal, (55). 
Divsalar, M. (2008). Look to east approach in foreign relations of Iran. Pegah biweekly, (37).

Divsalar, M. (2011). Iran and regional security in Central Asia. Defense strategy journal, (32).

Divsalar, M. (2014). Foreign policy of Iran toward SCO. Scientific-research journal, (47).

Javadi Vashki, E. (2015). Effect of security on foreign policy of Iran: case study of SCO and NATO member countries. M.A thesis. Political sciences. Islamic Azan University, Amol Branch.

Khoshandam, B. (2015). Iran and Shanghai Cooperation Organization: Reciprocal Strategies and Viewpoints. Retrieved from www.iranreview.org

Mattis, P. (2005). A Victory for China's New Security Concept: The Shanghai Cooperation Organization. China and Eurasia Forum Quarterly, Special Edition: The SCO at One, 3(2).

Vaezi, M. (2007). Challenges and security approach in environment of Iran.

\section{Copyrights}

Copyright for this article is retained by the author(s), with first publication rights granted to the journal.

This is an open-access article distributed under the terms and conditions of the Creative Commons Attribution license (http://creativecommons.org/licenses/by/4.0/). 